\title{
Isolation and characterization of novel microsatellite markers in Mercenaria mercenaria
}

\author{
Y.F. Ning ${ }^{1,2}$, Z.B. Li ${ }^{1,2}$, X.Q. Mao ${ }^{1,2}$, B.B. Li ${ }^{1,2}$, Y.S. Huang ${ }^{1,2}$, Y. Yuan ${ }^{1,2}$ and \\ J.B. Shangguan ${ }^{1,2}$ \\ ${ }^{1}$ Fisheries College, Jimei University, Xiamen, China \\ ${ }^{2}$ Fujian Provincial Key Laboratory of Marine Fishery Resources and Eco-Environment, \\ Xiamen, China \\ Corresponding author: Z.B. Li \\ E-mail: lizhongbao@jmu.edu.cn
}

Genet. Mol. Res. 15 (1): gmr.15017497

Received August 21, 2015

Accepted November 26, 2015

Published March 18, 2016

DOI http://dx.doi.org/10.4238/gmr.15017497

\begin{abstract}
Mercenaria mercenaria, also known as the hard clam, is widely distributed in the coastal waters of temperate and tropical areas in the Asian Pacific region. This species is widely popular in the international market, especially in the United States, Europe, and other Western countries, because of its high protein value, taste, and simple farming requirements. In this study, 17 novel microsatellite loci from the $M$. mercenaria genome were developed using the fast isolation by amplified fragment length polymorphism of sequences containing repeats protocol. Thirty-two wild individuals were used to evaluate the degree of polymorphism of these markers. Results indicated that there were 11 polymorphic loci and six monomorphic loci, and the number of alleles per locus and the polymorphism information content ranged from two to six and from 0.059 to 0.498 , respectively. The observed and expected heterozygosity varied from 0.0625 to 0.5333 and 0.0615 to 0.4977 , respectively. The $\mathrm{Y} 1-4$ locus deviated significantly from Hardy-Weinberg equilibrium (HWE) after Bonferroni correction was applied, while the other loci were in HWE. These loci will provide useful information for $M$. mercenaria population genetic studies.
\end{abstract}

Key words: Mercenaria mercenaria; Microsatellites; Genetic markers 


\section{INTRODUCTION}

Mercenaria mercenaria is also known as the hard clam because of its hard shell. This species is endemic to habitats in the Atlantic Ocean on the west coast of North America, north of the Gulf of St. Lawrence, and south of the Gulf of Mexico, and it inhabits areas from the intertidal zone to a seabed depth of $15 \mathrm{~m}$ (McHugh, 2001). M. mercenaria is widely popular in the international market, especially in the United States, Europe, and other Western countries because of its high protein value, taste, and simple farming requirements. It usually has strong environmental adaptability, including wide temperature and salt ranges (Ansell, 1968; Arnold et al., 1991; Rice and Pechenik, 1992). Considering that its geographical distribution (in terms of latitude and longitude) is the same in China, the key ecological factors in this region should also be suitable. Therefore, this species was first introduced from the United States to China in 1997 to promote shellfish consumption, to add new farming industry species, to promote the sustainable development of the aquaculture industry, and to further accelerate the development of beaches and ponds (Hoover, 2007; Wang and Zhang, 2011).

Microsatellite DNA, also as known as simple sequence repeats (SSR) or short tandem repeats (STR), refers to a handful nucleotides in the DNA sequence that are repeated in tandem several times (Cao et al., 2012). Compared with other molecular markers, non-coding microsatellite markers have high polymorphic information content (PIC), high repeatability, and co-dominant inheritance. Moreover, the markers are widely used in population genetics, population differentiation, linkage analyses, and evolutionary studies ( $\mathrm{Li}, 2006$; Li et al., 2013). Previous studies of $M$. mercenaria were mostly focused on morphology, artificial breeding, and environmental factors. Studies of the population structure of this economically valuable species remain insufficient, so studies on the development of genetic markers are urgently needed. In this study, a novel marker suite of 17 loci in M. mercenaria was developed, which may be useful for future studies associated with population genetics and the protection of species resources.

\section{MATERIAL AND METHODS}

Here, we report 21 microsatellite markers from $M$. mercenaria, which were identified using the fast isolation by amplified fragment length polymorphism of sequences containing repeats (FIASCO) protocol (Zane et al., 2002). High quality genomic DNA was extracted from the muscle tissues of a wild M. mercenaria individual collected from Xiamen, China using a genomic DNA extraction kit (Tiangen, Beijing, China) according to the manufacturer instructions. The DNA concentration was estimated using an ultraviolet spectrophotometer and electrophoresis on a $1 \%$ agarose gel. The DNA was then diluted to $100 \mathrm{ng} / \mu \mathrm{L}$, and it was digested for $10 \mathrm{~min}$ at $65^{\circ} \mathrm{C}$ with $10 \mathrm{U}$ restriction enzyme FastDigest Tru1l in a $25-\mu \mathrm{L}$ volume. The digested fragments (500 to $1200 \mathrm{bp}$ ) were purified and ligated to Msel adapter 1 (5'-ACGATGAGTCCTGAG-3')/Msel adapter 2 (5'-TACTCAGGACTCAT-3') using T4 DNA ligase (Fermentas, Vilnius, Lithuania) at $22^{\circ} \mathrm{C}$ overnight. The digestion-ligation mixture was then denatured and hybridized to the biotinlabeled oligo-nucleotide probes $(\mathrm{CT})_{15}$ and $(\mathrm{GT})_{15}$. Fragments containing microsatellite repeats were captured with Streptavidin-coated Magnetic Sphere Particles (Promega, Madison, WI, USA), and non-annealed DNA was washed away. The recovered products were amplified using Msel adapter1, and the PCR products were purified to remove extra dNTPs and adaptors. The purified products were ligated to the pMD19-T vector (Takara, Shiga, Japan), and were then transformed into Escherichia coli (Invitrogen, Carlsbad, CA, USA) for further selection on ampicillin plates. 
A total of 152 positive clones were amplified via colony-PCR using universal M13 primers. DNA fragments above 500 bp were sequenced by the Invitrogen Company (Shanghai, China), and 130 sequences with microsatellites were successfully obtained. Thirty-nine pairs of primers were designed using the Primer Premier version 5.0 software, and the amplification conditions for all primers were selected via optimization in an Eppendorf Mastercycler Gradient System (Eppendorf, Hamburg, Germany). Successful primers were validated using the genomic DNA of 32 wild $M$. mercenaria individuals that were collected from Xiamen, China. PCR amplification conditions consisted of a $10-\mu \mathrm{L}$ reaction mixture containing $50 \mathrm{ng}$ genomic DNA, 10X Taq buffer, $2 \mathrm{mM} \mathrm{MgCl}$, $0.4 \mu \mathrm{M}$ of each primer, $0.2 \mathrm{mM}$ of each dNTP, and $0.25 \mathrm{U}$ Taq DNA polymerase (Fermentas). PCR was carried out under the following conditions: pre-denature at $94^{\circ} \mathrm{C}$ for $5 \mathrm{~min}$; 37 cycles of denaturation at $94^{\circ} \mathrm{C}$ for $40 \mathrm{~s}$, annealing at an optimal temperature (Table 1) for $40 \mathrm{~s}$, and $72^{\circ} \mathrm{C}$ for $1 \mathrm{~min}$; and a final 10 -min elongation step at $72^{\circ} \mathrm{C}$. The PCR products were electrophoresed on $6 \%$ denaturing polyacrylamide gels in a Sequi-Gen Sequencing Cell (Bio-Rad, Hercules, CA, USA), and then visualized using silver staining.

Table 1. Statistical information associated with 17 microsatellite loci in Mercenaria mercenaria (32 individuals).

\begin{tabular}{|c|c|c|c|c|c|c|c|c|c|}
\hline GenBank accession No. & Locus ID & \begin{tabular}{|l|} 
Primer sequences $\left(5^{\prime}-3^{\prime}\right)$ \\
\end{tabular} & Repeat motif & $\mathrm{Ta}\left({ }^{\circ} \mathrm{C}\right)$ & $\mathrm{N}_{\mathrm{A}}$ & $\mathrm{PIC}$ & $H_{0}$ & $H_{\mathrm{E}}$ & Allele size (bp) \\
\hline KR704602 & $\mathrm{G}^{*}$ & $\begin{array}{l}\text { F:GGGTTAGTAGCATAGTCAGAAA } \\
\text { R:AAGAATCACGAAGACCAGAA }\end{array}$ & $(\mathrm{TTC})_{5}$ & 51 & 4 & 0.496 & 0.0417 & 0.3236 & $103-124$ \\
\hline KR704603 & G2 & $\begin{array}{l}\text { F:TGTCCAGCAAATAAATC } \\
\text { R:CTCAAAGGGAGGGTAT }\end{array}$ & $(\mathrm{TG})_{4}$ & 48 & 3 & 0.237 & 0.2812 & 0.2555 & $112-135$ \\
\hline KR704604 & G3 & $\begin{array}{l}\text { F:ACGGAGAAATCCCGAATA } \\
\text { R:CACGCAAGCAGCCATG }\end{array}$ & $(\mathrm{CGTG})_{3}$ & 53 & 2 & 0.134 & 0.1562 & 0.1463 & $225-232$ \\
\hline KR704605 & G4 & $\begin{array}{l}\text { F:TTGGCTAAAGTTATGCT } \\
\text { R:GATTCCTGCTAATGTTG }\end{array}$ & $(\text { ATA })_{3}$ & 52 & 2 & 0.059 & 0.0625 & 0.0615 & $215-236$ \\
\hline KR704606 & G5 & $\begin{array}{l}\text { F:ACGCAAAGACCTTTCATA } \\
\text { R:TGTTCAAACCCAAATACG }\end{array}$ & $(\text { TTA })_{3}$ & 49 & 5 & 0.300 & 0.3226 & 0.2840 & $187-213$ \\
\hline KR704607 & G6 & $\begin{array}{l}\text { F:TGTAAAAGAACCAAGGGG } \\
\text { R:AGCACCGTGAAAGTCAAT }\end{array}$ & $(\mathrm{AGAT})_{5}$ & 50 & 4 & 0.218 & 0.2500 & 0.2316 & $296-330$ \\
\hline KR704608 & G7 & $\begin{array}{l}\text { F:ATTGGGTAATTTCACAACA } \\
\text { R:AATAGCGTCATTCATCGT }\end{array}$ & $(\text { AATT })_{3}$ & 48 & 5 & 0.498 & 0.5333 & 0.4977 & 146-159 \\
\hline KR704609 & G8 & $\begin{array}{l}\text { F:GCTGGCGTGACGAATG } \\
\text { R:GGCTGCTGCTTGCTTT }\end{array}$ & $(\text { TCGC })_{3}$ & 52 & 3 & 0.348 & 0.3125 & 0.4330 & 273-294 \\
\hline KR704610 & G9 & $\begin{array}{l}\text { F:TGAAAACAAAACTCACA } \\
\text { R:AAAACTCGTGTATGGAC }\end{array}$ & $(\text { CATT })_{3}$ & 45 & 6 & 0.414 & 0.2903 & 0.4093 & $212-241$ \\
\hline KR704611 & G10 & $\begin{array}{l}\text { F:TTTCCATTGGCATTCAG } \\
\text { R:GTTCCTTCAGCTCCCTC }\end{array}$ & $(\text { ATT })_{3}$ & 48 & 2 & 0.195 & 0.2500 & 0.2222 & $136-144$ \\
\hline KR704612 & G11 & $\begin{array}{l}\text { F:CTATCTGTCCTTGAATCA } \\
\text { R:TTCTAAACCTGTGACCT }\end{array}$ & $\left(\right.$ TGT $_{5} \mathrm{~T}_{34}$ & 50 & 3 & 0.304 & 0.3438 & 0.3438 & $294-310$ \\
\hline KR704613 & G12 & $\begin{array}{l}\text { F:ACCGCACCTGACACTCT } \\
\text { R:ACGGGAACATCACCATC }\end{array}$ & $(\text { CTTGTC })_{3}$ & 49 & NA & NA & NA & NA & 242 \\
\hline KR704614 & G13 & $\begin{array}{l}\text { F:CATTTTGAAGCGGAGACT } \\
\text { R:TTGGGGACACCTTGAGT }\end{array}$ & $(\mathrm{AGC})_{3}$ & 47 & NA & NA & NA & NA & 211 \\
\hline KR704615 & G14 & $\begin{array}{l}\text { F:ATTGGGTAATTTCACAACA } \\
\text { R:AATAGCGTCATTCATCGT }\end{array}$ & $(\mathrm{AATT})_{3}$ & 48 & NA & NA & NA & NA & 169 \\
\hline KR704616 & G15 & $\begin{array}{l}\text { F:TAGTAACCCCAAATCTG } \\
\text { R:ATTATCTAAGCGAAACG }\end{array}$ & $(\mathrm{TC})_{33}$ & 42 & NA & NA & NA & NA & 255 \\
\hline KR704617 & G16 & $\begin{array}{l}\text { F:ATCTGCTCCTCTGATTGT } \\
\text { R:TTTGTCCTGGTTGTGC }\end{array}$ & $(\text { TTA })_{3}$ & 46 & NA & NA & NA & NA & 203 \\
\hline KR704618 & G17 & $\begin{array}{l}\text { F:TTCATCCATCGAGAATTG } \\
\text { R:GTGCTGCGAGTCTTACAT }\end{array}$ & $(\mathrm{CT})_{8}$ & 53 & NA & NA & NA & NA & 240 \\
\hline
\end{tabular}

Ta = annealing temperature; $N_{A}=$ number of polymorphic alleles per locus; $H_{0}=$ observed heterozygosity; $H_{E}=$ expected heterozygosity; $\mathrm{PIC}=$ polymorphism information content. *high significant deviations $(P<0.0045)$ from Hardy-Weinberg equilibrium after Bonferroni correction $(k=11)$.

In this study, we successfully amplified 17 novel microsatellite markers (Table 1), including 11 polymorphic microsatellite loci and six monomorphic loci. The number of alleles per locus and the PIC values were calculated using the POPGEN32 (version 1.32) software (Yeh et al., 2000), while the observed and expected heterozygosity values were calculated using the CERVUS 3.0 (version 2.2.3) software. Deviations from Hardy-Weinberg equilibrium (HWE) and genotypic linkage disequilibrium were also tested using POPGENE 32 (version 1.32). 


\section{RESULTS}

The results indicated that there were 11 polymorphic loci and six monomorphic loci, and the number of alleles per locus and the PIC values ranged from two to six and from 0.059 to 0.498 , respectively. The observed and expected heterozygosity values ranged from 0.0625 to 0.5333 and 0.0615 to 0.4977 , respectively. Loci Y1-4 deviated significantly from HWE after a Bonferroni correction was applied, but the other loci were in HWE.

\section{DISCUSSION}

Several reasons may contribute to this result, including natural selection, inbreeding, the Wahlund effect, null alleles, and size homoplasy (Chen et al., 2012). Moreover, the small sample size could account for the significant deviations from HWE. Therefore, in order to reveal the accurate genetic background of wild M. mercenaria, additional sample areas and larger sample sizes should be included in future studies. These novel M. mercenaria microsatellite markers increased the available molecular markers for this species. These loci will be useful for studies of genetic diversity, population structure, and conservation strategy design.

\section{Conflicts of interest}

The authors declare no conflict of interest.

\section{ACKNOWLEDGMENTS}

Research supported by the Natural Science Foundation of Fujian Province (\#2014J01133), the National Natural Science Foundation of China (\#31272668), the Foundation for Innovative Research Team of Jimei University, China (\#2010A004), and the Program for New Century Excellent Talents in Fujian Province University [\#(2006)35].

\section{REFERENCES}

Ansell AD (1968). The rate of growth of the hard clam Mercenaria mercenaria (L.) throughout the geographical range. $J$. Conseil 31: 364-409. http://dx.doi.org/10.1093/icesjms/31.3.364

Arnold WS, Marelli DC, Bert TM, Jones DS, et al. (1991). Habitat-specific growth of hard clams Mercenaria mercenaria (L.) from the Indian River, Florida. J. Exp. Mar. Biol. Ecol. 147: 245-265. http://dx.doi.org/10.1016/0022-0981(91)90185-Y

Cao Y, Li Z, Li Q, Chen X, et al. (2012). Development and characterization of microsatellite loci for Fenneropenaeus penicillatus Alcock. Afr. J. Biotechnol. 11: 10831-10833.

Chen XJ, Li ZB, Chen L, Cao YY, et al. (2012). Isolation and characterization of new microsatellite markers in the pen shell Atrina pectinata (Pinnidae). Genet. Mol. Res. 11: 2884-2887. http://dx.doi.org/10.4238/2012.May.22.4

Gallager SM and Mann R (1986). Growth and survival of larvae of Mercenaria mercenaria (L.) and Crassostrea virginica (Gmelin) relative to broodstock conditioning and lipid content of eggs. Aquaculture 56: 105-121. http://dx.doi.org/10.1016/0044$\underline{8486(86) 90021-9}$

Hoover EA (2007). Effects of temperature, salinity and dissolved oxygen on survival of triploid and diploid hard clams, Mercenaria mercenaria. Doctoral thesis, University of Florida.

Li QH, Li ZB, Dai G, Chen XJ, et al. (2013). Characterization of new microsatellite markers of Siganus fuscescens (Siganidae). Genet. Mol. Res. 12: 2751-2754. http://dx.doi.org/10.4238/2013.July.30.12

Li ZB (2006).The genetic diversity and differentiation of $H$. ovina populations by allozyme analysis. In: 13th International congress on genes, gene families and isozymes - ICGGFI (Xiong XG, Yan ZZ, and Liang WY, eds.). Medimond, 201-207. 
McHugh JL (2001). Management of hard clam stocks, Mercenaria mercenaria. In: Biology of the hard clam (Kraeuter JN and Castagna M, eds.). Elsevier, New York, 631-649.

Rice MA and Pechenik JA (1992). A review of the factors influencing the growth of the northern quahog, Mercenaria mercenaria (Linnaeus, 1758). J. Shellfish Res. 11: 279-287.

Wang $Q$ and Zhang $T$ (2011). The role of phosphatidylinositol signaling pathway in regulating serotonin-induced oocyte maturation in Mercenaria mercenaria. Chin. J. Oceanology Limnol. 29: 568. http://dx.doi.org/10.1007/s00343-011-0155-y

Yeh FC, Yang R, Boyle TJ, Ye Z, et al. (2000). PopGene32, Microsoft Windows-Based freeware for population genetic analysis, version 1.32. Molecular Biology and Biotechnology Centre University of Alberta, Alberta.

Zane L, Bargelloni L and Patarnello T (2002). Strategies for microsatellite isolation: a review. Mol. Ecol. 11: 1-16. http://dx.doi. org/10.1046/j.0962-1083.2001.01418.x 